\title{
Temporal change in IL-6 mRNA and protein expression produced by cyclic stretching of human pulmonary artery endothelial cells
}

\author{
KOZUE KOBAYASHI $^{1}$, MASUMI TANAKA ${ }^{2}$, SATORU NEBUYA ${ }^{1,3}$, KENICHI KOKUBO $^{1,3}$, YUTAKA FUKUOKA ${ }^{4}$, \\ YOSHITERU HARADA ${ }^{1,3}$, HIROUSKE KOBAYASHI ${ }^{1,3}$, MAKOTO NOSHIRO ${ }^{1,3}$ and HIDENORI INAOKA ${ }^{1,3}$ \\ ${ }^{1}$ Graduate School of Medical Science, ${ }^{2}$ School of Preventive Medicine, and ${ }^{3}$ School of Allied Health Sciences, \\ Kitasato University, Sagamihara, Minami-ku, Kanagawa 252-0373; ${ }^{4}$ Department of Biosystems Modeling, Graduate \\ School of Biomedical Science, Tokyo Medical and Dental University, Bunkyo-ku, Tokyo 113-8510, Japan
}

Received March 9, 2012; Accepted April 27, 2012

DOI: $10.3892 /$ ijmm.2012.1023

\begin{abstract}
The time courses of interleukin (IL)-6 gene expression and protein production were examined in human pulmonary artery endothelial cells (HPAECs) subjected to cyclic stretching. IL-6 protein was increased even in cells without stretching. Fold changes determined by dividing the level of IL-6 protein in stretched cells by that in unstretched cells at the same sampling times indicated that IL-6 protein was increased by stretching. At least $1 \mathrm{~h}$ of stretching was necessary to elicit an increase of IL- 6 protein, and the levels peaked at $3 \mathrm{~h}$ after the start of stretching. After withdrawal of stretching, there was no further increase of IL-6 protein. The expression levels of the IL- 6 gene were significantly increased by stretching and peaked at $30 \mathrm{~min}$ after the start of stretching. The difference in the peak times of IL- 6 gene and protein expression likely reflects the process of protein synthesis after the appearance of IL-6 mRNA.
\end{abstract}

\section{Introduction}

Mechanical ventilators are indispensable for patients with many types of respiratory failure so that vital organs can be adequately oxygenated. However, excessive mechanical ventilation may cause serious complications, one of which is ventilator-induced lung injury (VILI) (1-3). VILI leads to an increase of cytokine and/or chemokine production and alveolar-capillary permeability, promoting protein-rich edema formation, thus impairing gas exchange (4-6). In addition, it is generally agreed that VILI induces multiple organ failure (MOF), which can ultimately prove fatal. It has been suggested that VILI may trigger release of inflammatory mediators into

Correspondence to: Dr Kozue Kobayashi, Graduate School of Medical Science, Kitasato University, 1-15-1 Kitasato, Sagamihara, Minami-ku, Kanagawa 252-0373, Japan

E-mail: kozukoba@kitasato-u.ac.jp

Key words: time course, interleukin-6, lung injury, endothelial cell, cyclic stretching, inflammation the circulation, thereby exacerbating a pro-inflammatory systemic environment and eventually leading to detrimental effects in distal organs (7-9).

Pulmonary cells are overstretched when volumes in some areas in the lung are increased by mechanical ventilation $(10,11)$. The effects of cyclic stretching have been studied in various cell systems (12-18). Studies in vivo and in vitro have suggested that cell stretching induces gene expression and protein production of various inflammatory mediators, such as tumor necrosis factor (TNF)- $\alpha$, interleukin (IL)-1 $\beta$, IL-6, and IL-8 (19,20). Recently, it was shown that the expressions of early response genes [early growth response gene (EGR)1, heat shock protein (HSP)70, IL-1 $\beta$, IL-6, and macrophage inflammatory protein (MIP)-2] were changed by over-distension of the lungs in adult and newborn rats, before the appearance of overt lung injury (21). In those studies, however, the cells were stretched for only a few specific time periods, and the expressions of the genes/proteins of inflammatory mediators were often assessed only after stretching had been terminated or significant lung injury had occurred. None of the studies investigated the time courses of these changes in expression. Although it is now well known that specific mediators are involved in the pathogenesis of stretch-induced lung injury, only fragmentary evidence of their role in vivo and in vitro has been obtained (20-23). In other words, although the steady state of molecular systems causing VILI has been clarified to some extent, further understanding of the dynamics of these systems is still required.

The aim of this study was to examine time-courses of the gene expression and protein production of IL-6 in human pulmonary artery endothelial cells (HPAECs) when subjected to cyclic stretching. HPAECs were chosen for four reasons: i) To our knowledge, production of IL-6 protein by HPAECs subjected to cyclic stretching has not been investigated in detail in vitro. ii) The inflammatory mediators produced by HPAECs located on the surface of the pulmonary artery would easily pass into circulating blood. iii) Our previous study showed that the strain on HPAECs was nearly equal to that on a flexible silicoelastic membrane on which HPAECs were cultured (24). iv) Among cell lines derived from normal tissues in the lung, only HPAECs were available. IL-6 was chosen because our preliminary experiments had shown that, 
among various inflammatory mediators, IL-6 protein was that mainly produced by HPAECs subjected to cyclic stretching (25).

\section{Materials and methods}

Cell culture. HPAECs (CC-2530; Lonza) were cultured in a growth medium, EGM-2 Bullet kit ${ }^{\mathrm{TM}}$, consisting of EBM-2 and SingleQuots ${ }^{\mathrm{TM}}$ (human epidermal growth factor, heparin, hydrocortisone, FBS, ascorbic acid, vascular endothelial growth factor (VEGF), insulin-like growth factor (R3-IGF)-1 and GA-1000 $(50 \mathrm{mg} / \mathrm{ml}$ gentamicin, $50 \mu \mathrm{g} / \mathrm{ml}$ amphotericin B; CC-3162; Lonza). The concentrations of the added factors in SingleQuots are unpublished.

HPAECs passaged 7 times were seeded on 6-well flexible silicoelastic membrane culture plates (BioFlex ${ }^{\circledR}$ Culture Plates; Flexcell International) at a density of $2 \times 10^{4}$ cells $/ \mathrm{cm}^{2}$. The seeded area of the culture plate was where uniform strain was imposed on the cells (Fig. 1). Pre-culture was performed for $48 \mathrm{~h}\left(21 \% \mathrm{O}_{2}, 5 \% \mathrm{CO}_{2}, 37^{\circ} \mathrm{C}\right)$, after which the cells adhered tightly to the membrane.

Cyclic stretching. A flexcell strain unit (Flexercell ${ }^{\circledR} \mathrm{FX}-4000 \mathrm{~T}^{\mathrm{TM}}$ Tension System and BioFlex ${ }^{\circledR}$ Loading Stations ${ }^{\mathrm{TM}}$; Flexcell International) provided uniform strain on a membrane surface by application of vacuum pressure to a silicoelastic membrane (26). Deformation of the membrane led to the elongation of the cells adhering to its surface (Fig. 2).

Under our experimental conditions, the cyclic stretching comprised $20 \%$ elongations with a square waveform of 15 cycles/min, and the ratio of stretching to relaxation was $1: 2$. The $20 \%$ elongation is the maximum achievable with the FX-4000T ${ }^{\mathrm{TM}}$ using a circular loading post. Cyclic stretching that exceeds $15 \%$ elongation has been reported to be pathological (27-29). The waveform, cycle and ratio employed are equivalent to the clinical standards of mechanical ventilation, and thus mimicked excessive mechanical ventilation.

The longest stretching duration of $48 \mathrm{~h}$ was employed for two reasons. One is that the compliance of the membrane remained constant until stretching for $72 \mathrm{~h}$ (29), and the other is that the provider of the medium (Lonza) recommends replacement of the medium every $48 \mathrm{~h}$.

Production of cell cytokines. After pre-culture, the cells were stretched for various durations. The experiments were broadly divided into two groups because only four flexible bottom culture plates can be set simultaneously in the Loading Stations $^{\mathrm{TM}}$. Thus, four different durations of stretching are possible in a single experiment. In the first group, the durations were 1, 3, 6 and $12 \mathrm{~h}$. During the experiments, the cell supernatant was sampled at the time points indicated by the up-pointing arrows in Fig. 3. In the second group, the durations were 12, 24, 36 and $48 \mathrm{~h}$. During the experiments, the cell supernatant was sampled at the time points indicated by the up-pointing arrows in Fig. 4.

The supernatants of the cells that had been stretched in the two groups of experiments were assayed for the protein concentrations of IL-1 $\beta$, IL- 6 and IL- 8 by ELISA (KHC0011, KHC0061, KHC0081; Invitrogen) to clarify whether they had been increased by cyclic stretching.

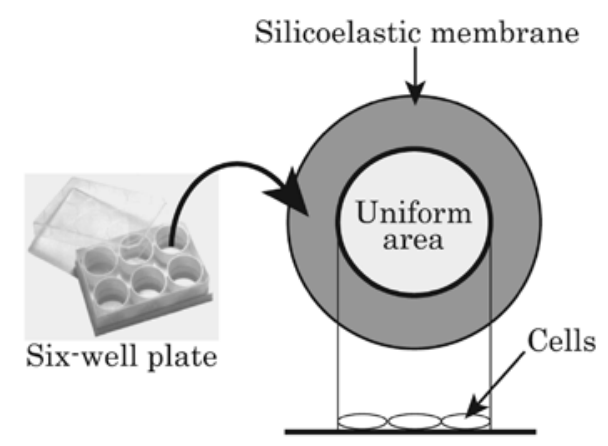

Figure 1. Area of uniform membrane strain in the 6-well plate.

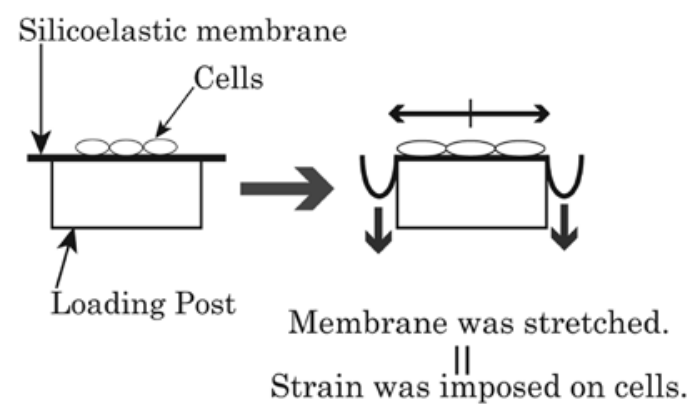

Figure 2. Membrane stretching by vacuum pressure. Deformation of the membrane led to elongation of cells adhering to its surface.

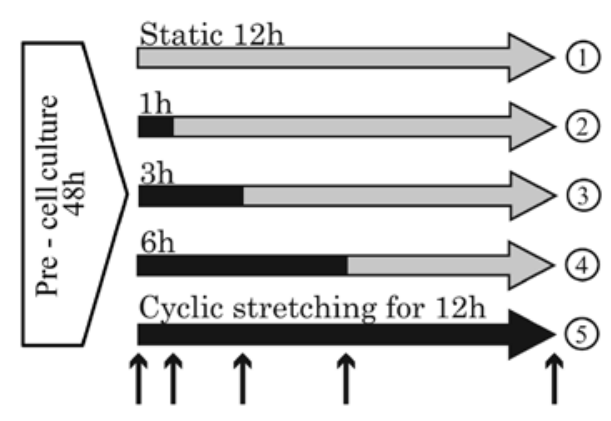

Experimental conditions

(1) Control (12h static)

(2) $1 \mathrm{~h} \mathrm{CS}+11 \mathrm{~h}$ static

(3) $3 \mathrm{~h} \mathrm{CS}+9 \mathrm{~h}$ static

(4) $6 \mathrm{~h} \mathrm{CS}+6 \mathrm{~h}$ static

(5) $12 \mathrm{~h} \mathrm{CS}$

$\mathrm{CS}=$ cyclic stretching

$\uparrow=$ Sampling of cell supernatant

Figure 3. Stretching durations $\leq 12 \mathrm{~h}$ and timings of sampling of cell supernatants for ELISA assay.

Real-time RT-PCR. After pre-culture, the cells were stretched for 5, 10 and $30 \mathrm{~min}$ and 1 and $3 \mathrm{~h}$. cDNA was synthesized from total-RNA, extracted from the cells before and after stretching (Fig. 5), using an iScript ${ }^{\mathrm{TM}}$ cDNA Synthesis kit (Bio-Rad Laboratories, Inc.). The real-time RT-PCR reaction was performed using a DNA Engine Opticon ${ }^{\circledR}$ system (BioRad Laboratories, Inc.) with primers for IL-6. Reaction data were normalized relative to the expression of GAPDH. 


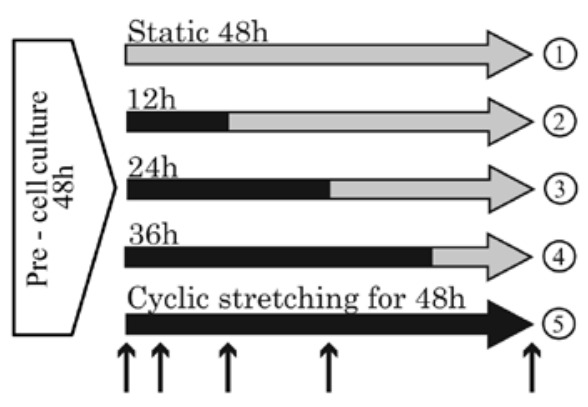

Experimental conditions

(1) Control (48h static)

(2) $12 \mathrm{~h} \mathrm{CS}+36 \mathrm{~h}$ static

(3) $24 \mathrm{~h} \mathrm{CS}+24 \mathrm{~h}$ static

(4) $36 \mathrm{~h} \mathrm{CS}+12 \mathrm{~h}$ static

(5) $48 \mathrm{~h} \mathrm{CS}$

$\mathrm{CS}=$ cyclic stretching

$\uparrow=$ Sampling of cell supernatant

Figure 4. Stretching durations from 12 to $48 \mathrm{~h}$ and timings of sampling of the cell supernatants for ELISA assay.

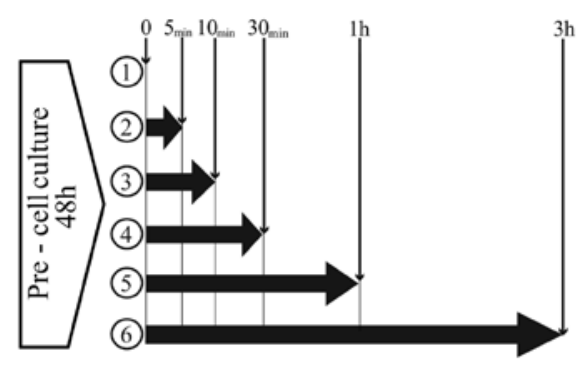

Experimental conditions

(1) Control (0min)

(2) $5 \mathrm{~min} \mathrm{CS}$

(3) $10 \mathrm{~min} \mathrm{CS}$

(4) $30 \mathrm{~min} C \mathrm{CS}$

(5) $1 \mathrm{~h} \mathrm{CS}$

(6) $3 \mathrm{~h} \mathrm{CS}$

$\Rightarrow=$ Cyclic stretching

$\downarrow=$ Extracted from cultured cells

$\mathrm{CS}=$ cyclic stretching

Figure 5. Stretching durations and timings of mRNA extraction from the cells for real-time RT-PCR analysis.

Statistical analysis. All measured experimental data are presented as fold-change (means $\pm \mathrm{SD}$ ) relative to control samples. The Kruskal-Wallis and Scheffe tests were used for statistical comparisons of the expression levels of both the IL-6 gene and protein. Significance was accepted at $\mathrm{P}<0.05$. All experiments were repeated 5 times independently $(n=5)$.

\section{Results}

Stretching duration and IL- 6 protein production. The fold changes shown in Fig. 6 were obtained by dividing the measured IL- 6 protein levels by the IL- 6 protein level before the start of stretching $(0 \mathrm{~h})$. The fold change in unstretched

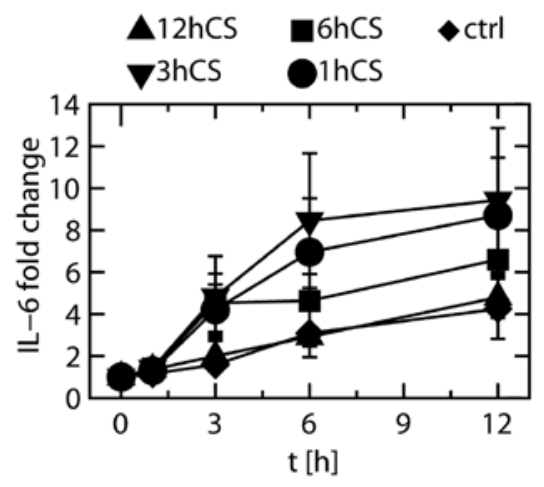

Figure 6. Fold changes in expression of IL-6 protein produced in response to cyclic stretching. Values were normalized relative to those before the start of stretching. ctrl denotes the data obtained from unstretched cells and CS cyclic stretching. Symbols represent the mean values from 5 experiments and vertical bars are the standard deviations.

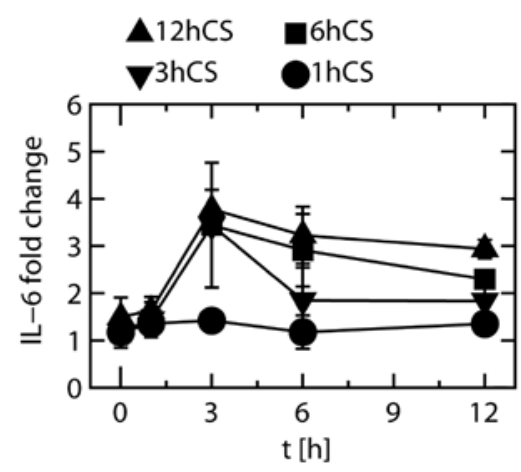

Figure 7. Fold changes in expression of IL-6 protein produced in response to cyclic stretching over a period of 0 to $12 \mathrm{~h}$. The data were normalized relative to those obtained from unstretched cells at the same time points. CS denotes cyclic stretching. Symbols represent mean values from 5 experiments and the vertical bars represent standard deviations.

(control) cells appeared to be increased at 3, 6 and $12 \mathrm{~h}$ after the start of stretching, but the increase was not statistically significant. When the cells were stretched, many significant differences were found in the IL- 6 protein levels at 3, 6 and $12 \mathrm{~h}$ relative to those in unstretched cells at the same time points. To show these increases more clearly, other fold changes were calculated by dividing the IL- 6 protein levels in the stretched cells by those in the unstretched cells at the same time points (Fig. 7). When the cells were stretched for $1 \mathrm{~h}$ and subsequently unstretched, the degree of increase in protein expression remained unchanged from 0 to $12 \mathrm{~h}$. When the cells were stretched for $3 \mathrm{~h}$ and subsequently unstretched, the fold change at $3 \mathrm{~h}$ was significantly higher than at any other time point. When the cells were stretched for $6 \mathrm{~h}$ and subsequently unstretched, the fold changes at 3 and $6 \mathrm{~h}$ were significantly higher than that at $0 \mathrm{~h}$, and the fold changes at 3 and $12 \mathrm{~h}$ were significantly higher than that at $1 \mathrm{~h}$. When the cells were stretched for $12 \mathrm{~h}$, the fold changes at 3,6 and $12 \mathrm{~h}$ were significantly higher than those at 0 and $1 \mathrm{~h}$.

These results showed that at least $3 \mathrm{~h}$ of stretching was necessary to increase the expression of IL- 6 protein, and that when stretching was discontinued after $3 \mathrm{~h}$ of stretching the protein expression did not increase further. 


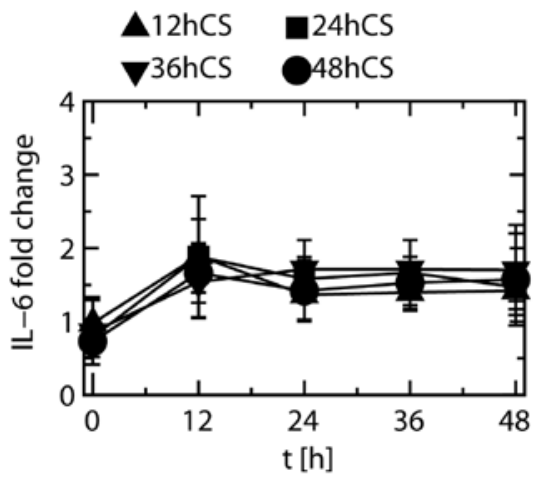

Figure 8 . Fold changes in the expression of IL-6 protein produced in response to cyclic stretching over a period of 0 to $24 \mathrm{~h}$. The data were normalized relative to those obtained from unstretched cells at the same time points. CS denotes cyclic stretching. Symbols represent mean values of 5 experiments, and the vertical bars represent standard deviations.

Expression of IL-1 $\beta$ protein was not detected at any time point, and the level of IL-8 protein showed no significant changes during cyclic stretching (data not shown).

Stretching duration and IL-6 protein production. Fold changes in the expression of IL-6 when the cells were stretched for 12, 24,36 and $48 \mathrm{~h}$ are depicted in Fig. 8. Most of the fold changes observed in the stretched cells showed no significant differences relative to that at $0 \mathrm{~h}$, irrespective of stretching duration.

IL-1 $\beta$ protein was not detected at any time point, and the level of IL-8 protein did not show any significant changes during cyclic stretching (data not shown).

Gene expression. The expression level of the IL-6 gene were significantly increased by stretching at all time points other than $1 \mathrm{~min}$, relative to the levels before the start of stretching. The level peaked at $30 \mathrm{~min}$ after the start of stretching (Fig. 9).

\section{Discussion}

The levels of IL-6 mRNA and protein peaked at $30 \mathrm{~min}$ and at $3 \mathrm{~h}$ of stretching, respectively. The difference in the peak times probably reflects the process of IL- 6 protein synthesis after the appearance of IL-6 mRNA.

IL-6 protein usually decays in serum in vivo $(30,31)$, but under our in vitro experimental conditions it did not do so, even without stretching. One possible explanation for this finding is that in vivo the IL-6 protein is eliminated by certain enzymes, which are lacking under in vitro conditions. Furthermore, the IL-6 protein is probably released from HPAECs without any stimulation when they are cultured in medium, as has been reported for the culture of human AG01522 fibroblasts (32).

Our finding that even when stretching was continued for $12 \mathrm{~h}$, there was no further increase in the IL- 6 protein level compared to $3 \mathrm{~h}$ of stretching, was in accordance to the finding that IL-6 mRNA expression was considerably reduced after $3 \mathrm{~h}$ of stretching in comparison to its peak (Fig. 9). As IL-6 protein expression was maximal after a specific duration $(3 \mathrm{~h})$ of cyclic stretching, it appears that timing is important when investigating interactions among inflammatory mediators and/ or their precursors.

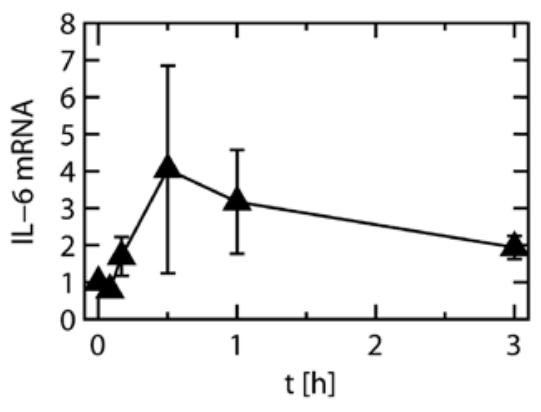

Figure 9. Changes in expression of IL-6 mRNA in response to cyclic stretching over a period of 0 to $3 \mathrm{~h}$. The data were normalized relative to those for GAPDH. Triangles represent mean values of 5 experiments, and vertical bars represent standard deviations.

\section{Acknowledgements}

This study was supported in part by a grant from Kitasato University School of Allied Health Sciences nos. 2010-1049 and 2011-1050 to K.K., no. 2011-1033 to M.N. and a scientific research grant from the Ministry of Education, Culture, Sports, Science and Technology of Japan (no. 23792084) to K.K.

\section{References}

1. Perker JC, Hernandez LA and Peevy KJ: Mechanisms of ventilator-induced lung injury. Crit Care Med 21: 131-143, 1993.

2. Pinhu L, Whitehead T, Evans T and Griffiths M: Ventilatorassociated lung injury. Lancet 361: 332-340, 2003.

3. Lionetti V, Recchia FA and Ranieri VM: Overview of ventilatorinduced lung injury mechanisms. Curr Opin Crit Care 11: 82-86, 2005.

4. Tremblay LN and Slutsky AS: Ventilator-induced injury: from barotraumas to biotrauma. Proc Assoc Am Physicians 110: 482-488, 1998.

5. Ricard JD, Dreyfuss D and Saumon G: Ventilator-induced lung injury. Eur Respir J Suppl 42: 2S-9S, 2003.

6. Tremblay LN and Slutsky AS: Ventilator-induced injury: from the bench to the bedside. Intensive Care Med 32: 24-33, 2006.

7. Slutsky AS and Tremblay LN: Multiple system organ failure. Is mechanical ventilation a contributing factor? Am J Respir Crit Care Med 157: 1721-1725, 1998.

8. Ranieri VM, Suter PM, Tortorella C, et al: Effect of mechanical ventilation on inflammatory mediators in patients with acute respiratory distress syndrome: a randomized controlled trial. JAMA 282: 54-61, 1999.

9. Plotz FB, Slutsky AS, van Vught AJ and Heijnen CJ: Ventilatorinduced lung injury and multiple system organ failure: a critical review of facts and hypotheses. Intensive Care Med 30: 1865-1872, 2004.

10. Mead J, Takishima T and Leith D: Stress distribution in lungs: a model of pulmonary elasticity. J Appl Physiol 28: 596-608, 1970.

11. Marini JJ: New opinions for the ventilator management of acute lung injury. New Horiz 1: 489-503, 1993.

12. Komuro I, Kaida T, Shibazaki Y, Kurabayashi M, Katoh Y, Hoh E, Takaku F and Yazaki Y: Stretching cardiac myocytes stimulates protooncogene expression. J Biol Chem 265: 3595-3598, 1990.

13. Iba T, Maitz S, Furbert T, Rosales O, Widmann MD, Spillane B, Shin T, Sonoda T and Sumpio BE: Effect of cyclic stretch on endothelial cells from different vascular bed. Circ Shock 35: 193-198, 1991.

14. Scott JE, Yang SY, Stanik E and Anderson JE: Influence of strain on $[3 \mathrm{H}]$ thymidine incorporation, surfactant-related phospholipid synthesis, and cAMP levels in fetal type II alveolar cells. Am J Respir Cell Mol Biol 8: 258-265, 1993.

15. Lyall F, Deehan MR, Greer IA, Boswell F, Brown WC and McInnes GT: Mechanical stretch increases protooncogene expression and phosphoinositide turnover in vascular smooth muscle cells. J Hypertens 12: 1139-1145, 1994. 
16. Wang DL, Wung BS, Shyy YJ, Lin CF, Chao YJ, Usami S and Chien S: Mechanical strain induces monocyte chemotactic protein-1 gene expression in endothelial cell. Effects of mechanical strain on monocyte adhesion to endothelial cells. Circ Res 77: 294-302, 1995

17. Pugin J, Dunn I, Jolliet P, Tassaux D, Magnenat JL, Nicod LP and Chevrolet JC: Activation of human macrophages by mechanical ventilation in vitro. Am J Physiol 275: L1040-L1050, 1998.

18. Vlahakis NE, Schroeder MA, Limper AH and Hubmayr RD: Stretch induces cytokine release by alveolar epithelial cells in vitro. Am J Physiol 277: L167-L173, 1999.

19. von Bethmann A, Brasch F, Muller KM and Uhlig S: Barotraumainduced cytokine and eicosanoid release from the isolated perfused and ventilated mouse lung. Am J Respir Crit Care Med 153: A530, 1996.

20. Tremblay L, Valenza F, Ribeiro SP, Li J and Slutsky AS: Injurious ventilatory strategies increase cytokines and c-fos m-RNA expression in an isolated rat lung model. J Clin Invest 99: 944-952, 1997.

21. Copland IB, Kavanagh BP, Engelberts D, McKerlie C, Belik J and Post M: Early changes in lung gene expression due to high tidal volume. Am J Respir Crit Care Med 168: 1051-1059, 2003.

22. Copland IB and Post M: Stretch-activated signaling pathways responsible for early response gene expression in fetal lung epithelial cells. J Cell Physiol 210: 133-143, 2007.

23. Ricard JD, Dreyfuss D and Saumon G: Production of inflammatory cytokines in ventilator-induced lung injury: a reappraisal. Am J Respir Crit Care Med 163: 1176-1180, 2001.

24. Kobayashi K, Kishi A, Tanaka M, Inaoka H, Nebuya S, Fukuoka Y, Kobayashi $\mathrm{H}$ and Noshiro M: Comparison of strains on a silicoelastic membrane and on cells adhering to the membrane. Trans Jpn Soc Med Biol Eng 47: 464-469, 2009 (In Japanese).
25. Kobayashi K, Tanaka M, Inaoka H, Nebuya S, Fukuoka Y, Kokubo K, Kobayashi $\mathrm{H}$ and Noshiro M: Temporal changes in gene expressions and cytokine productions caused by stretching of normal human pulmonary artery endothelial cells. Eur Respir J 36 (Suppl 54): 432s-433s, 2010.

26. Vande Geest JP, Di Martino ES and Vorp DA: An analysis of the complete strain field within Flexercell membranes. J Biomech 37: 1923-1928, 2004.

27. Birukov KG, Jacobson JR, Flores AA, Ye SQ, Birukova AA, Verin AD and Garcia JG: Magnitude-dependent regulation of pulmonary endothelial cell barrier function by cyclic stretch. Am J Physiol Lung Cell Mol Physiol 285: L785-L797, 2003.

28. Woodell JE, LaBerge M, Langan EM III and Hilderman RH In vitro strain-induced endothelial cell dysfunction determined by DNA synthesis. Proc Inst Mech Eng H 217: 13-20, 2003.

29. Tschumperlin DJ, Oswari J and Margulies AS: Deformationinduced injury of alveolar epithelial cells. Effect of frequency, duration, and amplitude. Am J Respir Crit Care Med 162: 357-362, 2004.

30. Saitoh T, Kokue E and Shimoda M: The impact of acute phase response on the plasma clearance of antipyrine, theophylline, phenytoin and nifedipine in rabbit. J Vet Pharmacol Ther 23: $153-158,2000$

31. Ramakers BP, de Goeij M, van der Hoeven JG, Peters WH and Pickkers P: Inflammation-induced hepatotoxicity in humans. Shock 31: 151-156, 2009.

32. Mariotti L, Facoetti A, Alloni D, Bertolotti A, Ranza E and Ottolenghi A: Effects of ionizing radiation on cell-to-cell communication. Radiat Res 174: 280-289, 2010. 